required by O'Hara's eclogite fractionation model ${ }^{11}$. Again, and contrary to O'Hara's belief, there is no way to match the observed rare earth variation along the Reykjanes Ridge with such an eclogitic fractional crystallization scheme.

Only a mixture composed of $95 \%$ clinopyroxene and $5 \%$ pyrope garnet could possibly bridge the rare earth pattern variation, but would require some $95 \%$ extract of such an unusual mixture. This is of course unacceptable, because the residual liquid of such an extract would have a major element chemistry quite distinct from an olivine tholeiite (the most common lava type over the Reykjanes Peninsula). It would also create a serious volume problem over and above having to explain the two to four times larger flux production of melt in the Iceland Region relative to more normal ridge segments, judging from crustal thickness ${ }^{2}$.

(3) "Extent of fractionation". Although it is true that there is a tendency for increasing fractionation for lava ascending through thicker crust (or altitude), it is untenable that the general trace element geochemical trend observed along the ridge can be accounted for by increasing fractional crystallization alone. As previously noted on the $[\mathrm{La} / \mathrm{Sm}]_{\mathrm{EF}} /[\mathrm{Yb}]_{\mathrm{EF}}$ diagram, the effect merely increases diversity and scatter about the general trend but cannot be responsible for it. Although at a first glance it may seem that altitude can be correlated with fractionation (such as reflected by the $[\mathrm{La} / \mathrm{Sm}]_{\mathrm{EF}}$ ), a simple plot of relevant data would show that it is not a regular and simple function. A corrollary of my plume model would be that basalt erupted south of $60^{\circ} \mathrm{N}$ be DLVL-derived and remain light REdepleted, even though water depth continues generally to increase along the ridge axis. A series of five new rock analyses for stations spaced from $60^{\circ} \mathrm{N}$ up to the Charlie Gibbs Fracture Zone $\left(\sim 53^{\circ} \mathrm{N}\right)$ shows a constant level for the $[\mathrm{La} / \mathrm{Sm}]_{\mathrm{EF}}$ just as south of $61^{\circ} \mathrm{N}$ (ref. 2, Fig. 3); and therefore further corroborates my model for two mantle sources of different densities and differentiation history.

O'Hara's preferred model of a single mantle source at the upper mantle-transition zone boundary ${ }^{1,12}$ offers little substance for discussion here, as it does not take into consideration the many geophysical-geochemical and geological features which contrast Iceland with the Mid-Atlantic Ridge. I do wish to emphasise that any alternative to my model should also satisfy these many model requirements, which I have listed and have taken into consideration in my model ${ }^{2}$.

Contrary to O'Hara's belief, I rejected the model of a single mantle source with increasing degree of fractional crystallization toward Iceland not only on the basis of isotopic ratios (evidence which for two mantle sources is overwhelming ${ }^{13}$ ), but also from rare earth considerations as outlined above and which I had to omit in my original discussion ${ }^{2}$ for the sake of brevity.

This work has been supported by the National Science Foundation.

\section{J.-G. SCHILLING}

Graduate School of Oceanography, University of Rhode Island, Kingston, RI 02881

Received July 18, 1973.

${ }^{1}$ O'Hara, M. J., Nature, 243, 507 (1973).

2 Schilling, J.-G., Nature, 242, 565 (1973).

${ }^{3}$ Schilling, J.-G., and Winchester, J. W., Science, N.Y., 153, 867 (1966).

- Philpotts, J. A., and Schnetzler, C. C., Geochim. cosmochim. Acta, 34, 307 (1970)

5 Masuda, A., and Kushiro, I., Contr. Mineral. Petrol., 26, 42 (1970).

${ }^{6}$ Schilling, J.-G., Nature phys. Sci., 242, 2 (1973).

A New English Dictionary (edit. by Murray, Sir James), 7, 1358 (Clarendon Press, Oxford, 1909).

${ }^{8}$ Schilling, J.-G., Phil. Trans. R. Soc., A268, 663 (1971)

๑ Schilling, J.-G., thesis, MIT (1966).
${ }^{10}$ Philpotts, J. A., Schnetzler, C. C., and Thomas, H. H., Geochim. cosmochim. Acta, 36, 1131 (1972).

11 O'Hara, M. J., and Yoder, H., Scottish J. Geol., 3, 67 (1967).

12 O'Hara, M. J., Phil. Trans. R. Soc., A268, 731 (1971).

${ }^{13}$ Hart, S. R., and Schilling, J.-G., Trans. Am. geophys. Un., 54, 484 (1973).

\section{Cavitation as a Mechanism for the Synthesis of Natural Diamonds}

LET us grant, in accordance with Galimov's proposals ${ }^{1}$, that cavitation can occur when flowing magma in a pipe encounters a constriction, and that in the ensuing collapse of a bubble very substantial transient dynamic pressures, of magnitude sufficient to be of thermodynamic importance for diamond synthesis, can be produced. In granting this, we overlook some quantitative details in his calculation, such as the apparent implication that the bubbles would contain gas at 10 or $20 \mathrm{kbar}$, and yet that their compression (by a factor of 64,000 in volume) can be calculated by ideal gas theory. He ignores the fundamental difference in rate control between martensitic conversion of crystals from one modification to another, which makes a product of the same chemical composition as the starting material, and other processes of crystal growth requiring a composition change. In the former class, to which production of diamond by the action of shock waves on graphite belongs, the limit on growth velocity is essentially the shock wave velocity. Thus, so far as that is concerned, quite a large diamond might be made within a few microseconds. Further characteristics of martensitic processes are, however, that the product takes the form of thin lenses, whereby the constraint by the matrix on shape change in the converting region is minimised and, second, that as a rule there is a multiplicity of orientations of the martensitic product in the parent crystal, so that a microcrystalline product results.

If the product is not to have the same chemical composition as the starting material, time must be allowed for diffusive segregation of chemical constituents. Galimov estimates the duration, $t_{\text {coll }}$, of dynamic pressure due to bubble collapse as $2 \times 10^{-3}$ s. In this time diffusive segregation could occur through a thickness of order $x=\left(D t_{\text {coll }}\right)^{\frac{1}{2}}$, where $D$ is the diffusion coefficient. With a fairly generous allowance of $10^{-4} \mathrm{~cm}^{2} \mathrm{~s}^{-1}$ for $D$ we have $x \sim 4.5 \mu \mathrm{m}$. The thickness of diamond which could grow from one seed in the given time could not exceed this and would be proportionately less in a medium of low concentration of carbon. Of course, repeated cavitations could give repeated periods of growth, but there is no apparent reason why re-solution would not occur in the much longer intervening periods of diamond instability. Galimov offers no estimate of the carbon content of the medium, except to indicate that $30 \%$ is too much. (There are, incidentally, no grounds whatever for his idea that a supersaturated solution of carbon from which diamond could grow would need a carbon concentration of this order of magnitude.)

Thus it is conceivable that some microdiamonds are produced under dynamic pressures due to cavitation in a fast flowing magma, either embedded in graphite or otherwise: and whereas the former might survive it is highly unlikely that the latter would. But it is quite certain that the recognised diamonds for which diamond mines are worked were not produced by this process. These diamonds, of fairly equant habit, and of dimensions of millimetres to centimetres as well as smaller, frequently show inescapable evidence of growth in successive shells on all sides, with discontinuities in the growth conditions, but continuity through thicknesses of tens or hundreds of micrometres, as well as (usually terminal) periods of resolution $^{2-6}$. These internal variations of impurity content and texture are readily explained by growth from solutions in times of at least the order of an hour, but quite inexplicable in terms of production by transient dynamic shock pressure. 
In brief, the sole basis of Galimov's claim, in connection with his postulated mechanism, that "there are no limitations involving the total concentration of carbon in the medium" is his complete disregard of such limitations, which are inescapable.

F. C. Frank

A. R. LANG

\section{H. H. Wills Physics Laboratory, University of Bristol, Bristol BS8 $1 T L$}

Physics Department,

Royal Holloway College, Englefield Green, Surrey TW20 OEX

\section{MORETON MOORE}

Received July 16, 1973.

1 Galimov, E. M., Nature, 243, 389 (1973).

2 Takagi, M., and Lang, A. R., Proc. R. Soc., A281, 310 (1964).

s Lang, A. R., Nature, 213, 248 (1967).

4 Frank, F. C., Proc. int. Industrial Diamond Conf., Oxford, 119 (Industrial Diamond Information Bureau, London, 1967).

${ }^{5}$ Moore, M., and Lang, A. R., Phil. Mag., 25, 219 (1972).

- Moore, M., and Lang, A. R., Phil. Mag., 26, 1313 (1972).

\section{BIOLOGICAL SCIENCES}

\section{A Novel Substituted Guanidine with High Activity in vitro against Rhinoviruses}

THE number and diversity of the viruses which infect the upper respiratory tract, and cause the common cold, virtually preclude the control of this disease by conventional vaccines. From this, apart from symptomatic therapy, the only hope for effective treatment of this most prevalent of diseases is in the development of broad spectrum antiviral drugs. We have developed a substituted guanidine, ICI 65,709 (ref. 1) (Fig. 1) which has good activity in vitro against all twentyfive rhinovirus serotypes tested in human embryonic lung cells, and also against certain other picornaviruses.

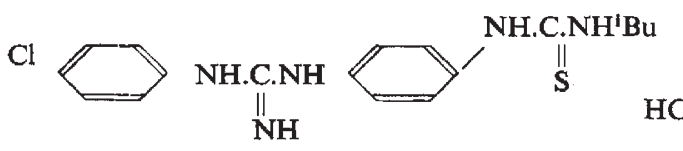

Fig. 1 The structural formula of ICI 65,$709 ; 1-p$-chlorophenyl3-( $m$ isobutylthioureido) phenyl guanidine hydrochloride.

The method of testing for antiviral activity has been fully described ${ }^{2,3}$. In brief, it consists of infecting tissue-culture cells in $3 \times 0.5$-inch tubes with $100 \mathrm{TCD}_{50}$ of test virus, and then adding the test compound in a range of concentrations. After incubation at $33^{\circ} \mathrm{C}$ for $2 \mathrm{~d}$, the cells are inspected with a low power microscope and the concentration of compound which causes $50 \%$ cytotoxicity and that which causes $50 \%$ inhibition of virus growth (cytopathic effect) are determined. From these values a tissue-culture 'therapeutic ratio' is calculated for each virus tested.

Table 1 shows that although the range of viruses tested was limited, it is clear that the activity of the compound is not confined to the rhinoviruses. Certain other picornaviruses were sensitive, and there was also some activity against vaccinia, herpes simplex, and the two arboviruses tested. The compound was inactive against equine rhinovirus, respiratory syncytial virus and the $229 \mathrm{E}$ strain of coronavirus, and also against influenza or parainfluenza grown in calf kidney cells.

A curious feature of the compound was that its antiviral action was highly dependent on the type of cell in which it is tested. For example, although the growth of rhinovirus type 2 in human embryonic lung cells is strongly inhibited by ICI 65,709 , the same virus grown in KB cells, HeLa or primary rhesus monkey kidney cells is completely insensitive to the compound. When rhinoviruses are grown in fragments of human embryonic trachea, $1 \mu \mathrm{g} \mathrm{ml}^{-1}$ ICI 65,709 inhibits growth by approximately $90 \%$.

Table $150 \%$ Toxic and 50\% Antiviral Concentrations of $\mid \mathrm{Cl} 65,709$ Against Various Viruses

\begin{tabular}{|c|c|c|c|c|}
\hline Cell type & $\begin{array}{l}50 \% \text { toxic } \\
\text { concen- } \\
\text { tration } \\
\left(\mu \mathrm{g} \mathrm{ml}^{-1}\right)\end{array}$ & Virus & $\begin{array}{l}50 \% \text { antiviral } \\
\text { concen- } \\
\text { tration } \\
\left(\mu \mathrm{g} \mathrm{ml}^{-1}\right)\end{array}$ & $\begin{array}{l}\text { Thera- } \\
\text { peutic } \\
\text { ratio } \\
\text { in vitro }\end{array}$ \\
\hline \multirow[t]{10}{*}{$\begin{array}{l}\text { Human } \\
\text { embryonic }\end{array}$} & 6 & $\begin{array}{l}\text { Rhinovirus type } \\
6,5,35 \\
33,3,44,40,1 \mathrm{~A}\end{array}$ & 0.4 & 15 \\
\hline & & & 0.2 & 30 \\
\hline & & $\begin{array}{l}1 \mathrm{~B}, 2 \\
15,16,31,4,26\end{array}$ & 0.1 & 60 \\
\hline & & $\begin{array}{l}36,17 \\
\text { Equine rhinovirus }\end{array}$ & $\begin{array}{c}0.05 \\
\text { Not active }\end{array}$ & 120 \\
\hline & & $\begin{array}{l}\text { Echovirus type } \\
11 \\
14\end{array}$ & $\begin{array}{l}0.05 \\
0.1\end{array}$ & $\begin{array}{r}120 \\
60\end{array}$ \\
\hline & & $\begin{array}{l}\text { Coxsackie virus } \\
\text { type }\end{array}$ & & \\
\hline & & $\begin{array}{l}\text { A } 9 \\
\text { A21 (Coe) } \\
\text { B3 }\end{array}$ & $\begin{array}{l}0.4 \\
0.8 \\
0.1\end{array}$ & $\begin{array}{r}15 \\
7 \\
60\end{array}$ \\
\hline & & Vaccinia & 0.2 & 30 \\
\hline & & $\begin{array}{l}\text { Herpes viruses: } \\
\text { H. simplex type } 1 \\
\text { H. simplex type } 2 \\
\text { Pseudorabies }\end{array}$ & $\begin{array}{c}1.0 \\
1.0 \\
\text { Not active }\end{array}$ & $\begin{array}{r}6 \\
6 \\
-\end{array}$ \\
\hline & & $\begin{array}{l}\text { Semliki forest } \\
\text { Sindbis }\end{array}$ & $\begin{array}{l}0.8 \\
0.8\end{array}$ & $\begin{array}{l}7 \\
7\end{array}$ \\
\hline \multirow{6}{*}{$\begin{array}{l}\text { Primary calf } \\
\text { kidney }\end{array}$} & 12 & Influenza & & \\
\hline & & & Not active & - \\
\hline & & $\mathbf{A}_{2}$ & Not active & - \\
\hline & & $\begin{array}{l}\text { Parainfluenza } 1 \\
\text { Respiratory }\end{array}$ & Not active & 一 \\
\hline & & syncytial & Not active & - \\
\hline & & Coronavirus $229 \mathrm{E}$ & Not active & - \\
\hline
\end{tabular}

Studies on the mode of action of ICI 65,709 using rhinovirus type 2 in human embryonic lung cells have shown that the compound does not destroy the rhinovirus virion, nor does it prevent the attachment or penetration of virus particles into the host cell. When the compound is added to virusinfected cells at various times after infection, and the virus yields at the end of the first growth cycle are measured, the compound is seen to exert progressively more inhibition of virus growth the longer it is present on the infected cell. This suggests an effect on a virus synthetic process which begins soon after eclipse and continues throughout the replicative process: possibly virus RNA or protein synthesis. The compound has no inhibitory effect on the RNA or protein synthesis of the host cell at concentrations up to 100 times the $50 \%$ antiviral level.

Although ICI 65,709 is a derivative of guanidine, its antiviral action differs from that of guanidine $e^{4}$ in at least two ways. First, it does not give rise to drug-resistance as does guanidine, and second, its action is not reversed by substances such as ethanolamine, choline, methionine, or lactalbumin hydrolysate ${ }^{5-8}$. Biochemical studies (Kolias, S. I., and Dim- 